\title{
Full Day School Implementation in Special Junior High School
}

\author{
Rizqi Fajar Pradipta \\ Special Need Education \\ State University of Malang, Indonesia \\ rizqi.fajar.fip@um.ac.id
}

\author{
Dimas Arif Dewantoro \\ Special Need Education \\ State University of Malang, Indonesia \\ dimas.arif.fip@um.ac.id
}

\author{
Umi Safiul Ummah \\ Special Need Education \\ State University of Malang, Indonesia \\ umi.safiul.fip@um.ac.id
}

\begin{abstract}
Full day school is a morning to evening learning for five days. This study uses a qualitative approach to the type of case study. The results showed that the implementation of full day school, which was initiated by the Ministry of Education and Culture, was carried out in the morning until noon which received support from the teachers, parents and students and brought good changes. Conclusion of the research results, the implementation of the full day scool program runs well and accordingly. Suggestions that can be done are considering students who are not able to attend full day school, more optimized means, evaluation and follow-up programs, as well as to other researchers in the future are expected to be more focused and thorough.
\end{abstract}

Keywords: full day school, special education, special junior high school

\section{INTRODUCTION}

Full day school is a five-day school run from morning to evening. According to Basuki (in Wicaksono, 2017) full day school is a school with part of the time used for informal learning programs, not rigid, fun, and requires creativity and innovation from the teacher. The learning process in school lasts longer not only in the classroom, because the concept of the formation of full day school is not to add teaching materials and lesson hours set by the Ministry of National Education as in the curriculum, but additional school hours for enrichment of teaching materials using creative learning methods and fun to use. add insight, complete tasks with teacher guidance, mentoring mentally, mentally, and morally children (Setiyorini, et al., 2014).

The same thing was conveyed by Basuki in (Wicaksono, 2017), stating that the effective time for children to learn is only 3-4 hours a day in a formal atmosphere and 7-8 hours, a day in an informal atmosphere, so in carrying out full day school use some time for the program informal learning that is not rigid, develops students' creativity and innovation from the teacher, as well as a pleasant atmosphere when learning. The implementation of full day school with a more enjoyable concept of learning also brings a lot of public anxiety, especially parents. Concerns from parents of students assume that full-day school will drain children's stamina, the condition of children who are tired after going home from school, the learning process requires a long concentration, will make students experience physical and psychological exhaustion (Commission X, 2017).

The existence of complaints from the public did not stop the full day school program from continuing. Some regular schools continue to run with new programs from the government, as well as special schools or Special Schools that educate children with special needs. According to Wiyani (2016) children with special needs are not weak and deprived, both mentally, emotionally and physically, even though they still have to get special treatment from others. The implementation of full day school in SLB becomes a learning program that can add insight or knowledge of children and children's independence. According to Wicaksono (2017) there is an additional learning program, of course the teacher needs to set the lesson schedule, because the priority in full day school is setting the subject schedule and deepening the learning material, even the curriculum will also be adjusted to the implementation of full day school in the special school.

Each school has their own goals, as in the example in Malang State University's SMPLB in implementing a full day school program it is necessary to design learning to be more interesting. According to Wiyani (2014) learning design is an effort of the teacher with regard to the process of determining learning objectives, strategies to achieve goals and designing media that can be used for the effectiveness of achieving goals. Based on the above phenomenon, the authors are interested in studying more about the implementation of full day school in Special Schools (SLB), especially Malang State High School which continues in the midst of the news of the advantages and disadvantages of full day school.

\section{METHODS}

The type of research in this study is qualitative, to describe in depth the events being studied in the form of descriptive data from the sources studied. The presence of researchers is full, because researchers are a key instrument in the implementation of this research. The study was carried out at SMPLB which has implemented the Full Day School education program. Data sources in qualitative research were obtained based on informants and recommendations from the informants so that the interviewees could get the things 
they observed and documented. According to Lofland and Lofland in Moleong (2015) the main data sources in qualitative research are words and actions, the rest are additional data such as documents and others. This research data source obtained is the result of interviews with the principal and the teacher in charge.

The technique used in data collection according to Sugiyono (2014) there are 3 kinds of techniques, namely observation or observation, in-depth interviews and documentation. Researchers in collecting data adopted data collection techniques from the theory by using three techniques namely observation or open observation, interviews and documentation. The data analysis technique used in this study is the Miles \& Huberman model, data analysis in this study ranging from data reduction, data presentation and data verification (Wiyono, 2007).

Checking the validity of findings in qualitative research is needed so that the data obtained can be accounted for. Researchers used 2 checking techniques to fulfill the trust aspects namely; (1) Triangulation, researchers in this study used two types of triangulation, namely source triangulation and technical triangulation, (2) Member Checking (Member Cheks). This research was conducted through several stages, including; (1) Pre-research phase, (2) Phase of conducting research, (3) Post-research phase.

\section{RESULT}

Based Education for children with special needs is not only enough to promote cognitive, affective and psychomotor aspects. The uniqueness of the ability of each student with special needs requires programs or types of activities that are diverse and useful for their lives. Various abilities possessed by children with special needs can be developed through selfdevelopment activities. Special Schools that provide services and education for $\mathrm{ABK}$ can include selfdevelopment activities in their school schedules. Adjusting to other lessons included in the school schedule, sometimes this self-development activity is carried out with a short time. Therefore, after an appeal to carry out a full day school, the SMPLB which initially carried out the school for six days changed to five days.

Planning for full day school programs is conducted with meetings between teachers, principals and committees, to obtain mutual agreement to implement changes from six days of study to five days of study. Then after getting an agreement from the school, the next step is to inform the student's guardian to get approval. After obtaining an agreement to implement a full day school, the school conducts the next plan regarding the activities to be carried out. This is what is meant by planning activities during the day.

Full day program implementation does not change the curriculum that has been used by schools. Morning activities are still the same as the six-day study or before full day. Emphasis on full day is learning time during the day. Activities take precedence in skills. Children have more study time and can focus more on learning skills. At first the skill was implemented, but the time was not longer at full day. Likewise schools do not make many changes in terms of facilities. During the daytime activities the school utilizes existing facilities to support children's learning. Full day school activities are carried out according to school plans. Starting from arranging schedules, dividing teacher assignments and learning activities in the classroom. Teachers who accompany each activity or who are responsible are teachers who have more understanding in their fields of self-development activities.

Self-development activities at SMPLB are a form of full day school program activities. This activity is carried out during the day. In the form of several types of activities that have been prepared according to the abilities and needs of students based on the results of assessment. Activities are carried out starting Monday to Friday. Monday to Thursday is a selfdevelopment activity from school and Friday is a compulsory scout activity in the 2013 curriculum.

Full day implementation at SMPLB received a positive response in the form of support from parents to include their children in full day school programs. Positive responses were also obtained from students who felt happy to be carried out full day because they had more time at school so they could play with their friends. When full day students have longer study time so they can maximize their learning process. Students can focus more on their interest talents that are channeled into self-development activities during the daytime. Learners are more skilled because they have longer study time and focus on activities that suit their needs.

\section{Discussion}

Sudarsini Based on the appeal from the Ministry of Education and Culture regarding Permen No. 23 of 2017 concerning School Days which regulates schools 8 hours a day or five days. SMPLB is encouraged to make changes to learning programs. At first the school ran for six days, starting from Monday to Friday. The schedule change to five days certainly has a longer study time at school. The aim is to provide the best educational services for students.

The schedule will be more compacted into five days, with additional study time during the day. The school divides the morning and afternoon study schedules with a number of breaks twice. In the morning the school agreed to carry out academic learning and self-development learning during the daytime. This is in accordance with the meaning of Full day school according to Iftayani \& Nurhidayati (2016), namely the education system that implements full day learning by integrating an intensive learning system that is to add hours to deepening the material as well as selfdevelopment and creativity.

At full day school, self-development activities are more focused, so there are classes for each type of activity. Each class will be accompanied by one teacher in charge of the activity and assisted by another teacher. Schools continue to use the 2013 curriculum. It's just that there is focusing on activities during the day.

The school arranges the schedule to be five days with two breaks, namely the first morning break and the second afternoon break. In the morning the 
school carries out academic learning and is usually carried out in their respective classes. During the day the school carries out self-development learning. The school has an entry schedule starting at 07.30 WIB, academic learning is carried out in accordance with the 2013 curriculum. After the first learning is completed, students can take a break from 09:45 to 10:00 WIB. In the second hour after the break the students reimplement the classroom learning. Exactly at 11.00 WIB is the second break. During this break, all students who take full day get ready to carry out the dhuhur prayers in congregation at the SMPLB mosque.

And conducted Friday prayers for male students at the mosque near the school, along with the accompanying teacher. Some students also take advantage of time for lunch and get ready for activities during the day. Exactly at 1:00 p.m., students who take full day schools prepare equipment and go to their respective activities.

Students have different activities according to their abilities and types of activities that have been prepared. During the afternoon learning, students can become one group in one type of activity with friends between classes and from some disabilities . Learning is carried out at the same time, with different tasks for each student. The assignment is adjusted according to the ability of each child. For example, for sewing activities, there are children who sew according to the lines that have been drawn on the cloth, there are those who sew by sticking pieces of cloth. Learning takes place from 1:00 p.m. to 2:30 p.m. WIB. After that students can go home. This is in line with Bahruddin which was conveyed in (Azizah, 2014) that the priority in full day school is the arrangement of subject schedules and deepening with the duration of time that runs from 08.00-15.00 WIB.

Self-development activities at SMPLB can run well starting with the assessment first. At the beginning of school, students have been assessed for their interest talents by including psychological test results and the teacher fills the instruments in the assessment process. The goal is to know the talents and interests of children. In addition to the initial assessment, the classroom teacher also conducts direct observations on the ability of children's activities every day, so that teachers have special notes to report during joint meetings. Each class teacher will report the results of his observations and be used as material in determining the type of activities that are appropriate to the needs and abilities of the child and then included in a structured schedule.

Self-development activities are carried out on afternoon learning from Monday to Thursday and on Friday Scouting activities are carried out in accordance with the recommendations in the 2013 Curriculum on compulsory Scout activities. In each type of activity can be carried out in a place that is comfortable and appropriate, so it is not required to be in the classroom. This is in line with the theory on the meaning of full day school, that is, the process of learning in school with a longer time, takes place not only in the classroom, because the concept of the formation of full day school does not add teaching material and class hours set by the Ministry of National Education as in the curriculum, but the school hours added to enrichment teaching materials use creative and fun learning methods to add insight and knowledge, complete tasks with teacher guidance, mental guidance, mental and moral children (Setiyorini, et al., 2014).

The full day program implementation is influenced by one factor, namely the supporting factor. First, from the school, all teachers in particular, have an agreement to make changes, namely to carry out full day school. The second supporting factor comes from parents of students. According to Junior \& Sadewo (2015) there are several reasons parents choose a school with a full day school program for their children, namely parents from the category of mothers who do not work and fathers work to choose full day school so that their children have a cognitive, emotional and spiritual smart character.

The third factor is from students. Positive response with the full day they carry out. Based on the theory presented by Dalvi (2013), with full day learning students spend a lot of time in school, in a wellprogrammed learning environment with a variety of positive activities, thus making students avoid bad influences of the environment as well as technology. This is in accordance with the conditions on the ground that students feel more happy when they are in school longer, because they can have more time to play with their friends. Students enjoy the time while having lunch together and carrying out fun self-development activities. After the full day school program is implemented, the school must also know the effectiveness of the program implemented.

The effort to find out the effectiveness of a program is to conduct an evaluation process. Ralph Tyler (in Arikunto \& Jabar, 2014) suggests that program evaluation is a process to find out whether educational goals can be realized. Then the information is used as a consideration in making a decision. The school carries out the process of evaluating a full day school program at the end of the year. Each class teacher prepares each student's report regarding changes and their learning outcomes after full day. The report results from each class teacher are used as consideration to find out the effectiveness of the full day program at SMPLB.

Based on the results of the reports from each teacher, it was found that students experienced better development, especially in terms of independence and the ability to carry out a task. Students have progress in self-sufficiency in eating alone with friends, more skilled at self-development activities for example are able to wash motorbikes using tools such as dust absorbers, water spraying machines, foam, and motor dryers in cleaning service activities. The effectiveness of programs in education also influences the effectiveness of student learning outcomes. The effectiveness of student learning outcomes can be known from the results of their learning. The learning outcomes of students at SMPLB after and before being implemented full day school turned out to bring better change. The full day school program has several advantages including; (1) can increase the potential and talent of students in terms of subjects, arts and sports, 
(2) can repeat lessons that are not understood, and (3) can improve learning outcomes and improve friendship with school citizens (Negoro, 2014).

At the time before full day school is implemented, students only have a short time in learning self-development. Short learning time makes students less focused on training their skills. Not finished completing the task, it must be stopped immediately because the time is up and replaced with other lesson schedules. In the end, students have not been able to learn optimally, and have not been able to optimize the ability of their talents and interests.

When implemented full day school, students have a longer study time, starting from the morning until the afternoon. Longer study time makes students focus more on training their skills. Especially in the more structured implementation time, namely in the morning can study academically and during the day can learn self-development. Students can learn more optimally. As a result they are more skilled at selfdevelopment activities that are useful for independence in their lives.

\section{Conclusion}

Process of the realization of a full day school program begins with the Ministry of Education and Culture's appeal and runs well according to the planning stages. The planning phase of the implementation of full day school is by holding a meeting between the teacher council and the school committee to get a joint agreement to carry out full day school. The meeting was held to discuss the school schedule from six days to five days, longer study time at school starting at 7:30 to 14:30 WIB. Early morning learning activities are academic learning in accordance with the 2013 curriculum and self-development activities are carried out during the day.

\section{Suggestion}

It is expected that self-development activities can continue to be carried out and developed in accordance with the conditions of students and schools, so that students with special needs can get maximum results in the implementation of full day school programs for their independence. For other researchers, it is hoped that they can find out more about the implementation of full day at other special schools, so that they can help provide plans for program activities for the development of full day activities in special schools.

\section{REFERENCES}

[1] Iftayani, I., \& Nurhidayati. 2016. Self Concept Self Esteem and School System: The Study of Comparation Between Fullday and Half Day School in Purworejo. Guidena Journal, 6(1).

[2] Dalvi. 2013. Penerapan Manajemen Kurikulum pada Sekolah Full Day di SDIT Cahaya Hati Kota Bukittinggi. Jurnal al-Fikrah, 6(1).

[3] Junior, M. S., \& Sadewo, F. X. S. 2015. Rasionalitas Orang Tua Memilih SD Program Full Day School di Kota Kediri. Jurnal Paradigma, 3(3).
[4] Setyorini, I. N., Sutarno J., \& Sunardi. 2014. Penerapan Sistem Pembelajaran "Fun and Full Day School" untuk Meningkatkan Religiusitas Peserta Didik di SDIT Al Islam Kudus. Jurnal Teknologi Pendidikan dan Pembelajaran, 2(2).

[5] Wicaksono, A. G. 2017. Fenomena Full Day School dalam Sistem Pendidikan Indonesia. Jurnal Komunikasi Pendidikan, 1(1).

[6] Wiyono, B. B. 2007. Metodologi Penelitian (Pendekatan Kualitatif, Kuantitatif dan Action Research). Malang: Universitas Negeri Malang

[7] Sugiyono. 2014. Memahami Penelitian Kualitatif. Bandung: Alfabeta.

[8] Wicaksono, A. G. 2017. Fenomena Full Day School dalam Sistem Pendidikan Indonesia. Jurnal Komunikasi Pendidikan, 1(1).

[9] Moleong, L. J. 2015. Metodologi Penelitian Kualitatif. Bandung: PT Remaha Rosdakarya.

[10] Wiyani, N. A. 2014. Desain Pembelajaran Pendidikan. Yoyakarta: Ar-Ruzz Media. 